\title{
PENGARUH KONSEP DIRI DAN KEDISIPLINAN BELAJAR TERHADAP PENGUASAAN KONSEP IPA
}

\author{
DIYAN MARLINA \\ dian.marlina@ikippgrimadiun.ac.id. \\ IKIP PGRI Madiun
}

\begin{abstract}
The aim of this research is to determine the influense of self-concept and discipline in learning, either directly or indirectly on mastery of concepts of natural science. The research method used was a survey, with a sample size of 75 students, drawn by simple random sampling technique from primary school in the area of South Jakarta. Data collection used a questionnaires that have been validated and the data values from the results of the written test students. Data analisys used path analisy, with the first test of normality, linearity test and multikolinearity test. The implications of this study were obtained, namely: that there is a direct influence on the discipline of self-concept study is $r_{12}=0,617$ and $P_{21}=0,617$, there is a direct influence on concept mastery learning discipline of natural science is $r_{12}=0,407$ and $P_{21}=0,306$, self-concept does not directly influence mastery of concepts of natural science is $r_{13}=0,352$ and $P_{31}=0,163$.

Keywords: self-concept, discipline to learn, mastery of the concept of natural sciences.
\end{abstract}

\begin{abstract}
ABSTRAK
Penelitian ini bertujuan untuk mengetahui pengaruh variabel konsep diri dan kedisiplinan belajar, baik secara langsung maupun tidak langsung terhadap penguasaan konsep IPA. Metode penelitian yang digunakan adalah survei, dengan jumlah sampel 75 orang, yang diambil dengan teknik random sampling dari SD swasta di wilayah Jakarta Selatan. Pengumpulan data menggunakan angket yang telah divalidasi dan data nilai dari hasil test tertulis siswa. Analisis data menggunakan analisis jalur, dengan terlebih dahulu dilakukan uji normalitas, uji linieritas dan uji multikolinieritas. Dari penelitian ini diperoleh Implikasi yaitu : bahwa terdapat pengaruh langsung konsep diri terhadap kedisiplinan belajar sebesar $r_{12}=0,617$ dan $P_{21}=0,617$, terdapat pengaruh langsung kedisiplinan belajar terhadap penguasaan konsep IPA sebesar $\mathrm{r}_{12}=0,407$ dan $\mathrm{P}_{21}=0,306$, konsep diri tidak berpengaruh langsung terhadap penguasaan konsep IPA sebesar $\mathrm{r}_{13}=0,352$ dan $\mathrm{P}_{31}=0,163$.
\end{abstract}

Keywords: konsep diri, kedisiplinan belajar, penguasaan konsep IPA. 


\section{A. PENDAHULUAN}

Pendidikan merupakan usaha yang sengaja dan terencana untuk membantu perkembangan potensial anak bermanfaat bagi kepentingan hidupnya sebagai seorang pribadi dan sebagai seorang anggota masyarakat. Pendidikan akanberjalan dengan baik, apabila masalah pendidikan tidak hanya tergantung pada baiknya program-program yang telah disusun dari tersediannya sarana dan prasarana yang lengkap tetapi juga tersediannya tenaga baru yang terdidik. Pembangunan Nasional di bidang pendidikan adalah upaya demi mencerdaskan bangsa dan meningkatkan kualitas manusia Indonesia yang memungkinkan masyarakatanya mengembangkan diri guna menguasai ilmu pengetahuan dan teknologi. Demi mewujudkan pembangunan di bidang pendidikan diperlukan peningkatan dan penyempurnaan penyelenggaraan pendidikan nasional yang disesuaikan dengan perkembangan ilmu pengetahuan dan teknologi serta kesenian dan perkembangan masyarakat.
Dalam kurikulum pendidikan di Indonesia pelajaran Ilmu Pengetahuan Alam merupakan salah satu mata pelajaran yang diberikan pada sejak jenjang pendidikan SD sampai SMA di Indonesia. Ilmu Pengetahuan Alam (IPA) berkaitan dengan cara mencari tahu tentang fenomena alam secara sistematis, sehingga IPA bukan hanya penguasaan kumpulan pengetahuan yang berupa fakta-fakta, konsepkonsep, atau prinsip-prinsip saja tetapi juga merupakan suatu prosespenemuan. Pendidikan IPA diharapkan dapat menjadi wahana bagi peserta didik untuk mempelajari diri sendiri dan alam sekitar, serta prospek pengembangan lebih lanjut dalam menerapkannya di dalam kehidupan sehari-hari. Proses pembelajaran menekankan pada pemberian pengalaman langsung untuk mengembangkan kompetensi agar peserta didik menjelajahi dan memahami alam sekitar secara ilmiah. Pendidikan IPA diarahkan untuk mencari tahu dan berbuat sehingga dapat membantu peserta didik untuk memperoleh pemahaman 
yang lebih mendalam tentang alam sekitar.

$$
\text { Maskoeri Jasin }
$$
mendefiniskan "IPA merupakan ilmu pengetahuan yang mengkaji gejalagejala dalam alam semesta, termasuk bumi ini, sehingga terbentuk konsep dan prinsip". Maskoeri menambahkan, IPA hanya mengkaji konsep-konsep dan prinsip-prinsip dasar yang esensial saja. Dalam ilmu pengetahuan, istilah ilmu pengetahuan alam merujuk kepada pendekatan logis untuk mempelajari alam semesta. Ilmu pengetahuan alam mempelajari alam dengan menggunakan metode-metode sains.

$$
\text { Penguasaan konsep IPA }
$$

adalah suatu kemampuan menemukan ide abstrak dalam IPA untuk mengklasifikasi objek-objek yang biasanya dinyatakan dalam suatu istilah kemudian dituangkan ke dalam contoh, sehingga seseorang dapat mengerti/memahami suatu konsep dengan jelas. Seseorang yang menguasai konsep dapat menggolongkan dan memiliki keterampilan untuk mengaplikasikannya dalam IPA dan dunia sekitarnya menurut konsep itu.
Faktor yang turut mempengaruhi penguasaan konsep IPA adalah sebaik apakah konsep diri siswa tersebut. Konsep diri terdiri dari bagaimana seseorang melihat diri sendiri sebagai pribadi, bagaimana seseorang merasa tentang diri sendiri dan bagaimana seseorang menginginkan diri sendiri menjadi manusia sebagaimana yang diharapkan. Konsep diri tidak serta merta ada bersamaan dengan ketika seseorang dilahirkan. Konsep diri berasal dan berakar pada pengalaman masa kanak-kanak dan berkembang, terutama sebagai akibat dari hubungan seseorang dengan orang lain dan bagaimana orang lain memperlakukan dirinya (orangtua, saudara kandung, sekolah, teman sebaya, masyarakat, pengalaman). Hal itu akan membentuk gagasan dalam diri seseorang seperti apakah seseorang itu sebagai pribadi. Konsep diri yang tinggi/positif akan membawa siswa pada sikap optimis dan percaya diri dan mampu menyelesaikan setap masalahyang dihadapinya khususnya permasalahan dalam pembelajarannya. Sikap inilah yang membuat siswa lebih berhasil 
dalam menyelesaikan tugas-tugas pembelajarannya. Sebaliknya dengan konsep diri yang rendah/negatif akan membawa siswa pada sikap pesimis, sehingga kurang percaya dalam menghadapi tugas-tugas pembelajarannya, yang berakibat kurang berhasilnya siswa dalam menyelesaikan tugas-tugas pembelajarannya.

Faktor lain yang turut mempengaruhi penguasaan konsep IPAadalah kedisiplinan belajar siswa tersebut. Disiplin menggambarkan perilaku yang mencerminkan tanggungjawab terhadap kehidupan, tanpa paksaan dari luar. Seseorang dikatakan berdisiplin kalau ia mampu mengendalikan tingkah lakunya. Kemampuan ini berasal dari dalam diri subyek itu sendiri, sehingga dengan pengendalian diri dia mampu menyesuaikan tingkah lakunya dengan norma-norma atau peraturanperaturan yang ada diluar dirinya. Seseorang dinyatakan disiplin diri, jika ia mampu mengarahkan tingkah lakunya sesuai dengan kebutuhannya dan selaras pula dengan patokanpatokan tingkah laku yang berlaku. Individu yang mempunyai tingkat konsep diri tinggi maka semakin tinggi pula tingkat kedisiplinannya. Begitu pula sebaliknya, semakin rendah konsep diri individu maka semakin rendah pula tingkat kedisiplinannya (Yoan Destarina, 2007). Natalia Florida (2012) dalam penelitiannya mengatakan bahwa, "ada hubungan yang positif dan signifikan antara konsep diri dengan dengan intensi kedisiplinan siswa. Dapat disimpulkan bahwa konsep diri secara signifikan dapat meningkatkan intensi kedisiplinan siswa."

Dari uraian di atas, peneliti melakukan penelitian dengan mengangkat variabel konsep diri, kedisiplinan belajar dan penguasaan konsep Fisika. Dengan dugaan terdapat pengaruh tidak langsung konsep diri terhadap penguasaan konsep IPA melalui kedisiplinan belajar. 


\section{B. METODE PENELITIAN}

Penelitian ini mengambil lokasi di daerah DKI Jakarta. Wilayah penelitian meliputi daerah kotamadya Jakarta Selatan yaitu di SD swasta yang sederajat, dengan asumsi dapat mempresentasikan pengaruh konsep diri terhadap penguasaan konsep IPA. Pemilihan lokasi ini dilakukan untuk mempermudah pengambilan data dari sampel dan kesesuaian dengan ruang lingkup penelitian. Sekolah yang dijadikan target penelitian adalah SD Cyber Media Jakarta Selatan, SD Wisata Indonesia Jakarta Selatan, dan SD Kemala Bayangkari Jakarta Selatan.Penelitian ini berlangsung selama 6 bulan, dilaksanakan pada bulan Agustus sampai dengan bulan Januari 2015.

Metode yang digunakan dalam penelitian ini adalah metode survei dengan teknik analisis jalur. Supardi (2012:263) menyatakan bahwa, "analisis jalur adalah suatu teknik pengembangan dari regresi linear berganda". Dalam analisis jalur (path analysis) ada tiga variabel yang diteliti yaitu variabel bebas (independent variable) yang terdiri atas satu variabel yakni Konsep Diri
Siswa, variabel mediator (intervening variable) yang terdiri atas satu variabel yakni Kedisiplinan Belajar Siswa, dan variabel terikat (dependent variabel) yakni Penguasaan KonsepIPA.

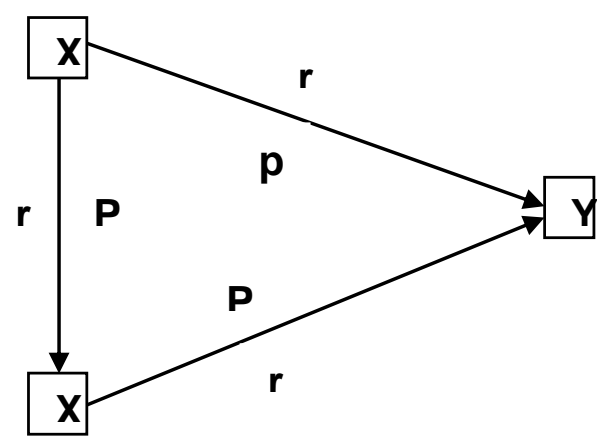

Gambar 1.1. paradigma penelitian

Keterangan :

X1 : Konsep Diri Siswa

X2 : Kemandirian Belajar Siswa

X3 : Penguasaan Konsep IPA

\section{HASIL DAN PEMBAHASAN}

\section{Analisis Deskripstif}

Penguasaan konsep IPA diperoleh menggunakan data hasil tes yang diselenggarakan oleh peneliti dengan 30 soal. Penguasaan konsep IPAdiperoleh skor sebagai berikut, jumlah responden 75 orang dengan rentang skor 27, dengan skor terendah 70 dan tertinggi 97. Skor rata-rata mereka adalah 87,20; modus 93, median 87, dan standar deviasi 7,239. 
Data tentang konsep diri diperoleh menggunakan instrumen berbentuk angket sejumlah 32 butir soal dengan rentang skor 1-5 point. Konsep diri diperoleh skor sebagai berikut, jumlah responden 75 siswa dengan rentang skor 76, dengan skor terendah 76 dan tertinggi 115. Skor rata-rata mereka adalah 96,87; modus 99, median 98, dan standar deviasi 8,296. Data tentang kedisiplinan belajar diperoleh menggunakan instrumen berbentuk angket sejumlah 28 butir soal dengan rentang skor 1-5 point. Kedisiplinan belajardiperoleh skor sebagai berikut, jumlah responden 75 siswa dengan rentang skor 37, dengan skor terendah 79 dan tertinggi 116. Skor rata-rata mereka adalah 99,68; modus 99, median 99, dan standar deviasi 8,399.

\section{Pengujian Persyaratan Data}

Data yang telah dikumpulkan selanjutnya diuji persyaratan analisis, yang meliputi uji normalitas, uji linearitas, dan uji kolinieritas. Hasil pengujian normalitas menggunakan Analisis Kolmogorov Smirnov dalam SPSS 20.0diperoleh hasil bahwa seluruh variabel berdistribusi normal. Hasil pengujian linieritas menggunakan ANOVA dalam SPSS 20.0 diperolah hasil bahwa model regresi yang terbentuk antara kedua variabel adalah linier. Hasil pengujian kolinieritas menggunakan VIF (Variance Inflation Factor) dalam SPSS 20.0 diperoleh hasil bahwa terdapat dugaan bebas dari adanya kolinieritas antara variabel konsep diri dengan kedisiplinan belajar.

\section{Pengujian Hipotesis Penelitian}

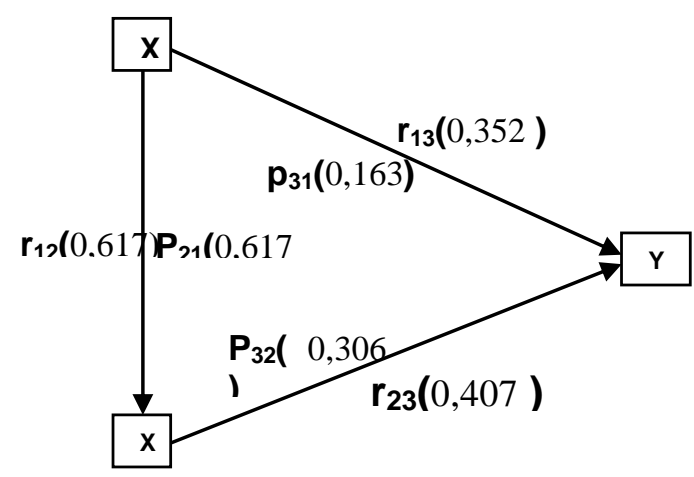

Gambar 1.2 Diagram Koefisien Korelasi dan Koefisien Jalur Keterangan : koefisien korelasi (r), koefisien jalur (p)

Berdasarkan analisis jalur diketahui bahwa koefisien jalur variabel konsep diri (X1) terhadap kedisiplinan belajar (X2) adalah $\mathrm{p}_{21}=\mathrm{b}_{21}=0,617$ dan diperoleh nilai $\mathrm{t}$ hitung 6,707.Nilai $\alpha=0,05 \mathrm{dan} \mathrm{dk}=$ $\mathrm{n}-\mathrm{k}-1=75-1-1=73$ pada uji dua pihak diperoleh nilai $\mathrm{t}_{\text {tabel }}=\mathrm{t}_{\mathrm{t}}=$ 
1,992. Karena nilai $t_{h}>t_{t}(6,707>$ 1,992) maka tolak $\mathrm{H}_{0}$ dan terima $\mathrm{H}_{1}$ dan disimpulkan terdapat pengaruh langsung yang signifikan konsep diri siswa terhadap kedisiplinan belajar siswa.

Berdasarkan analisis jalur diketahui bahwa koefisien jalur variabel konsep diri (X1) terhadap penguasaan konsep fisika (Y) adalah $\mathrm{p}_{31}=\mathrm{b}_{31}=0,167$ dan diperoleh nilai $\mathrm{t}-$ hitung 1,206 . Untuk $\alpha=0,05 \mathrm{dan} \mathrm{dk}$ $=\mathrm{n}-\mathrm{k}-1=75-2-1=72$ pada uji dua pihak diperoleh nilai $\mathrm{t}_{\text {tabel }}=\mathrm{t}_{\mathrm{t}}=$ 1,993. Karena nilai $t_{h}<t_{t}(1,206<$ 1,993) maka terima $\mathrm{H}_{0}$ dan tolak $\mathrm{H}_{1}$ dan disimpulkan tidak terdapat pengaruh langsung yang signifikan konsep diri siswa terhadap penguasaan konsep IPA siswa.

Berdasarkan analisis jalur diketahui bahwa koefisien jalur variabel kedisiplinan belajar (X2) terhadap penguasaan konsep IPA (Y) adalah $\mathrm{p}_{32}=\mathrm{b}_{32}=0,306$ dan diperoleh nilai t-hitung 2,258. Untuk $\alpha=0,05$ dan $\mathrm{dk}=\mathrm{n}-\mathrm{k}-1=75-2-1=72$ pada uji dua pihak diperoleh nilai $t_{\text {tabel }}$ $=t_{t}=1,993$. Karena nilai $t_{h}<t_{t}(2,258$ $<1,993$ ) maka tolak $\mathrm{H}_{0}$ dan terima $\mathrm{H}_{1}$ dan disimpulkan terdapat pengaruh langsung yang signifikan kedisiplinan belajar siswa terhadap penguasaan konsep IPA siswa.

Berdasarkan analisis jalur diketahui bahwa koefisien jalur variabel konsep diri terhadap penguasaan konsep IPA melalui kedisiplinan belajar $\mathrm{p}_{123}=\mathrm{p}_{21} \times \mathrm{p}_{32}=$ $0,617 \times 0,306=0,1889$. Jika dibandingkan dengan nilai $\mathrm{p}_{31}(0,163)$ maka nilai $\mathrm{p}_{123}=0,1889>\mathrm{p}_{31}=0,163$ . Hal ini mengintreprestasikan bahwa variabel intervening berpengaruh tidak langsung yang signifikan terhadap penguasaan konsep IPA. Untuk $\alpha=0,05$ dan $\mathrm{dk}=\mathrm{n}-\mathrm{k}-1=$ $75-2-1=72$ pada uji dua pihak diperoleh nilai $t_{\text {tabel }}=t_{t}=1,993$. Karena nilai $t_{h}<t_{t}(1,7889<1,993)$ maka terima $\mathrm{H}_{0}$ dan tolak $\mathrm{H}_{1}$ dan disimpulkan tidak terdapat pengaruh tidak langsung yang signifikan konsep diri terhadap penguasaan konsep IPA melalui kedisiplinan belajar siswa.

\section{Pembahasan}

Setelah dilakukan rangkaian penelitian maka dapat disimpulkan bahwa terdapat pengaruh langsung yang signifikan konsep diri terhadap kedisiplinan belajar. Hasil penelitian 
menunjukkan bahwa terdapat korelasi yang signifikan antara konsep diri (X1) dengan Kedisiplinan belajar (X2), hal ini ditunjukkan oleh angka koefisien korelasi sebesar $r_{12}=0,617$ dan sig $<0,05$ pada analisis korelasi dan koefisien jalur X1 terhadap X2 $\left(\mathrm{p}_{21}\right) \quad$ sebesar $0,617 . \quad$ Kontribusi langsung konsep diri (X1) terhadap kedisiplinan belajar (X2) sebesar $0,617^{2} \times 100 \%=38,067 \%$. Nilai tersebut telah di uji taraf signifikansinya dengan menggunakan uji-t menyatakan bahwa t-hitung sebesar 6,707. Demikian maka $: t_{h}>t_{t}$ $(6,707>1,992)$ tolak H0 dan terima $\mathrm{H} 1$, artinya koefisien jalur X1 terhadap X2 signifikan dan secara statistik bermakna.Hal ini sangat logis, sesuai dengan pendapat Desmita (2009 : 172), “konsep diri bukanlah sesuatu yang dibawa sejak lahir. Kita tidak dilahirkan dengan konsep diri tertentu. Bahkan ketika kita lahir, kita tidak memiliki konsep diri. Konsep diri terbentuk melalui proses belajar yang berlangsuntg sejak masa pertumbuhan hingga dewasa." Konsep diri lebih jauh ditunjukkan melalui faktor-faktor psikologis yang dimiliki oleh siswa.
Siswa dengan konsep diri baik akan mampu bertanggung jawab terhadap hidup dan kehidupannya, atau dengan kata lain, siswa tersebut memiliki kesadaran tentang masa depannya kelak. Kondisi ini tentunya akan memberikan pemahaman bahwa untuk berhasil, mereka harus belajar, dan memberikan yang terbaik untuk masa depan mereka sendiri. Menurut Prijodarminto (Tulus, 2004), “disiplin sebagai kondisi yang tercipta dan terbentuk melalui proses dari serangkaian perilaku yang menunjukkan nilai-nilai ketaatan, kepatuhan, kesetiaan, keteraturan dan ketertiban." Nilai-nilai tersebut telah menjadi bagian perilaku dalam kehidupannya. Perilaku itu tercipta melalui proses binaan melalui keluarga, pendidikan dan pengalaman. Menurut Omrod (2009), "Pembelajaran sebagai perubahan jangka panjang dalam representasi atau asosiasi mental sebagai hasil dari pengalaman". Disiplin belajar juga bisa diartikan sikap atau tingkahlaku siswa yang taat dan patuh untuk dapat menjalankan kewajibannya untuk belajar, baik belajar di sekolah maupun belajar di rumah. Indikator 
disiplin belajar dalam penelitian ini adalah: ketaatan terhadap tata tertib sekolah, ketaatan terhadap kegiatan belajar di sekolah, ketaatan dalam mengerjakan tugas-tugas pelajaran, dan ketaatan terhadap kegiatan belajar di rumah. Tentunya, siswa yang mepunyai kedisiplinan belajar juga didukung oleh konsep diri siswa yang baik/positif.

Hasil penelitian menunjukkan bahwa terdapat korelasi yang tidak signifikan antara konsep diri (X1) terhadap penguasaan konsep IPA (Y), hal ini ditunjukkan oleh angka koefisien korelasi sebesar $r_{13}=0,352$ dan sig. $<0,05$ pada analisis korelasi dan koefisien jalur X1 terhadap $\mathrm{Y}$ $\left(\mathrm{p}_{31}\right)$ sebesar 0,163. Kontribusi langsung konsep diri (X1) terhadap penguasaan konsep IPA (Y) sebesar $0,163^{2} \times 100 \%=2,657 \%$. Nilai tersebut telah di uji taraf signifikansinya dengan menggunakan uji-t menyatakan bahwa thitung sebesar 1,206. Dengan demikian maka : $\mathrm{t}_{\mathrm{h}}<\mathrm{t}_{\mathrm{t}}(1,206<1,993)$ terima $\mathrm{H}_{0}$ dan tolak $\mathrm{H}_{1}$, artinya koefisien jalur $\mathrm{X} 1$ terhadap $\mathrm{Y}$ tidak signifikan dan secara statistik tidak bermakna sehingga terdapat pengaruh langsung yang tidak signifikan konsep diri terhadap penguasaan konsep IPA

Hasil penelitian menunjukkan bahwa terdapat korelasi yang signifikan antara kedisiplinan belajar (X2) terhadap penguasaan konsep IPA (Y), hal ini ditunjukkan oleh angka koefisien korelasi sebesar $\mathrm{r}_{23}=$ 0,407 dan sig. $<0,05$ pada analisis korelasi dan koefisien jalur X2 terhadap $\mathrm{Y} \quad\left(\mathrm{p}_{32}\right)$ sebesar 0,306. Kontribusi langsung kedisiplinan belajar (X2) terhadap penguasaan konsep IPA (Y) sebesar $0,306^{2} \mathrm{x}$ $100 \%=9,364 \%$. Nilai tersebut telah di uji taraf signifikansinya dengan menggunakan uji-t menyatakan bahwa thitung sebesar 2,258. Dengan demikian maka $: \mathrm{t}_{\mathrm{h}}<\mathrm{t}_{\mathrm{t}}(2,258<1,993)$ tolak $\mathrm{H} 0$ dan terima $\mathrm{H} 1$, artinya koefisien jalur X2 terhadap Y signifikan dan secara statistik bermakna sehingga terdapat pengaruh langsung yang signifikan kedisiplinan belajar terhadap penguasaan konsep IPA. Menurut Prijodarminto (Tulus, 2004), “disiplin sebagai kondisi yang tercipta dan terbentuk melalui proses dari serangkaian perilaku yang menunjukkan nilai-nilai ketaatan, kepatuhan, kesetiaan, keteraturan dan 
ketertiban." Nilai-nilai tersebut telah menjadi bagian perilaku dalam kehidupannya. Perilaku itu tercipta melalui proses binaan melalui keluarga, pendidikan dan pengalaman. Menurut Omrod (2009), “ Pembelajaran sebagai perubahan jangka panjang dalam representasi atau asosiasi mental sebagai hasil dari pengalaman". Disiplin belajar juga bisa diartikan sikap atau tingkahlaku siswa yang taat dan patuh untuk dapat menjalankan kewajibannya untuk belajar, baik belajar di sekolah maupun belajar di rumah. Indikator disiplin belajar dalam penelitian ini adalah: ketaatan terhadap tata tertib sekolah, ketaatan terhadap kegiatan belajar di sekolah, ketaatan dalam mengerjakan tugas-tugas pelajaran, dan ketaatan terhadap kegiatan belajar di rumah. Siswa yang mepunyai kedisiplinan belajar yang tinggi akan diikuti semakin tingginya penguasaan konsep IPA.

Berdasarkan hasil penelitian yang telah dilakukan diperoleh nilai koefisien korelasi X1 terhadap X2 sebesar $\mathrm{r}_{12}=0,617$ dan $\mathrm{X} 1$ terhadap $\mathrm{Y}$ sebesar $r_{13}=0,352$ serta $X 2$ terhadap Y sebesar $r_{23}=0,407$. Sementara itu
Koefisien jalur pengaruh tidak langsung konsep diri (X1) terhadap penguasaan konsep IPA (Y) melalui kedisiplinan belajar (X2) ditentukan dari hasil kali koefisien jalur X1 ke $\mathrm{X} 2$ dan X2 ke Y. Koefisien jalur pengaruh tidak langsung $\mathrm{X} 1 \mathrm{ke} \mathrm{Y}$ melalui $\mathrm{X} 2$ yaitu : $\mathrm{p}_{21} \times \mathrm{p}_{32}=0,617 \mathrm{x}$ $0,306=1,889 \times 100 \%=18,89 \%$. Jika dibandingkan dengan nilai $\mathrm{p}_{31}(0,163)$ maka nilai $\mathrm{p}_{123}=1,889>\mathrm{p}_{31}=0,163$. Hal ini mengintreprestasikan bahwa variabel intervening berpengaruh secara signifikan terhadap penguasaan konsep IPA. Dari hasil pengujian yang telah dilakukan taraf signifikansinya menyatakan bahwa nilai $t_{\text {hitung }}$ adalah sebesar1,7889. Sementara itu nilai $t_{\text {tabel }}$ adalah sebesar 1,993. Dengan demikian maka: $t_{\text {hitung }}<t_{\text {tabel }}(1,7889<1,993)$, maka terima $\mathrm{H}_{0}$ dan tolak $\mathrm{H} 1$, artinya koefisien jalur dari $\mathrm{X}_{1}$ terhadap Ymelalui $\mathrm{X}_{2}$ tidak signifikan dan secara statistik tidak bermakna sehingga terdapat pengaruh tidak langsung yang tidak signifikan konsep diri terhadap penguasaan konsep IPA melalui kedisiplinan belajar.. 
Seperti telah dijelaskan ditetapkan bersama, baik persetujuan sebelumnya bahwa penguasaan tertulis maupun tidak tertulis antara konsep IPA adalah kemampuan seseorang dalam memahami konsepkonsep pada IPA. Pemahaman seseorang itu bisa benar dan bisa salah sesuai dengan pemahaman yang ia tangkap dalam pengertian IPA tersebut. Dengan menguasai konsep seseorang dapat menggolongkan dan memiliki keterampilan untuk mengaplikasikannya dalam IPA dan dunia sekitarnya menurut konsep itu. Konsep diri sebagai bentuk kepercayaan diri siswa terhadap dirinya sendiri, meliputi citra diri, harga diri dan lain sebagainya, merupakan sebuah faktor psikologis yang penting. Konsep diri yang baik berawal dari latar belakang lingkungan yang baik, lingkungan yang selalu mengajarkan untuk percaya kepada diri sendiri, percaya kepada kemampuan diri sendiri dan dapat bekerja sama dengan orangorang di sekitarnya. Dan selanjutnya, Disiplin belajar adalah suatu sikap, tingkah laku dan perbuatan siswa untuk melakukan aktivitas belajar yang sesuai dengan keputusan, peraturan, dan norma yang telah peserta didik dengan pendidik di sekolah maupun dengan orang tua di rumah. Indikator disiplin belajar dalam penelitian ini adalah: ketaatan terhadap tata tertib sekolah, ketaatan terhadap kegiatan belajar di sekolah, ketaatan dalam mengerjakan tugastugas pelajaran, dan ketaatan terhadap kegiatan belajar di rumah.

\section{PENUTUP}

\section{Simpulan}

Berdasarkan hasil analisis dan pengujian hipotesis maka hasil penelitian dengan judul pengaruh konsep diri dan kedisiplinan belajar terhadap penguasaan konsep IPA menunjukkan bahwa: 1) terdapat pengaruh langsung yang signifikan konsep diri terhadap kedisiplinan belajar; 2) terdapat pengaruh langsung yang tidak signifikan konsep diri terhadap penguasaan konsep IPA; 3)terdapat pengaruh langsung yang signifikan kedisiplinan belajar terhadap penguasaan konsep IPA; 4) terdapat pengaruh tidak langsung yang tidak signifikan konsep diri terhadap penguasaan konsep fisika melalui kedisiplinan 
belajar. Dengan semakin tingginya konsep diri dan kedisiplinan belajar siswa maka semakin tinggi pula penguasaan konsep IPA.

\section{Saran}

Berdasarkan hasil pengolahan data dan kesimpulan, maka penulis berupaya memberikan beberapa saran sebagai berikut:

1. Guru diharapkan selalu meningkatkan wawasan dan kemampuannya dalam hal bagaimana cara mendampingi peserta didik untuk menemukan jati diri sehingga mempunyai konsep diri yang jelas, dan dapat belajar dengan optimis dan meningkatkan kedisiplinan siswa.

2. Seorang siswa diharapkan dapat meningkatkan pandangan yang positif terhadap dirinya sendiri, seseorang yang mampu memberi penghargaan yang positif terhadap dirinya sendiri, akan memiliki konsep diri yang positif misalnya saja dengan selalu berfikir bahwa dirinya adalah orang yang berharga, mempunyai kemampuan, dan memiliki pemikiran bahwa setiap manusia pasti memiliki kelebihan, jangan selalu memikirkan kekurangan diri sendiri.

3. Disiplin diri yang dimiliki seseorang tidak tumbuh dengan sendirinya, melainkan dibentuk serta berkembang melalui latihan dan pendidikan sehingga terbentuk kesadaran dan keyakinan dalam dirinya untuk berbuat tanpa paksaan untuk guru harus terus meningkatkan kedisilplinan siswa.

4. Pembekalan teori-teori, konsepkonsep dan aspek-aspek yang dimiliki guru yang berhubungan dengan mata pelajaran fisika, hendaknya dikembangkan dan ditingkatkan.

\section{DAFTAR PUSTAKA}

Agustian, Hendriati. 2006. Psokologi Perkembangan. Bandung: Refika Aditama.

Aunurrahman. 2009. Belajar dan Pembelajaran. Bandung: Alfabeta.

Baihaqi, MIF. 2008. Psikologi Pertumbuhan. Bandung: Remaja Rosdakarya.

Budikase, dkk. 2004. Kurikulum dan Materi Fisika SMU. Jakarta: Universitas Terbuka.

Desmita. 2009. Psikologi Perkembangan Peserta Didik. 
Bandung: Remaja Rosdakarya.

Dimyati dan Mujiono. 2009. Belajar dan Pembelajaran. Jakarta: Rineka Cipta

Jasin, Maskoeri. 2009. Ilmu Alamiah Dasar. Jakarta: PT. Raja Grafindo Persada.

Mulyasa, E. Standar Kompetensi Guru dan Sertifikasi. Bandung: Remaja Rosdakarya.

Omrod, Jeanne Ellis. 2009. Psikologi Pendidikan. Jakarta: Erlangga.

Rakhmat, Jalaluddin. 2009. Psikologi Komunikasi. Bandung: Remaja Rosdakarya.

Sagala, Syaiful. 2010. Konsep Dan Makna Pembelajaran. Bandung: Alfabeta.

Supardi. 2012. Aplikasi Statistika Dalam Penelitian. Jakarta: PT. Ufuk Publishing House.
Sutikno, Sobry. 2009. Belajar dan Pembelajaran. Bandung: Prospect.

Tulus, Tu'u. 2004. Peran Disiplin Pada Perilaku dan Prestasi Siswa.. Jakarta: Grasindo.

Destriana, Yoan. 2007. Korelasi Antara Konsep diri dengan Tingkat Kedisiplinan Pada Anggota Kesatuan Aksi Mahasiswa Muslim Indonesia (KAMMI) Malang. Digital library UIN Maulana malik Ibrahim. http://lib.uinmalang.ac.id/?mod=th_detail \&id=01410003. 4 Juli 2014.

Florida, Natalia. 2012. Hubungan Antara Konsep Diri Dengan Intensi Kedisiplinan Siswa Kelas VIII SMP Negeri 2 Salatiga Semester Gasal tahun Plajaran 2012/2013. Universitas Kristen Satya wacana Instutional repository. http://repository.library.uksw. edu/handle/123456789/2947. 4 Juli 2014. 